Article

\title{
Investigating the Dietary Habits of Male Irish Farmers to Prevent Mortality and Morbidity
}

\author{
Diana van Doorn ${ }^{1}{ }^{D}$, Noel Richardson ${ }^{1, *}$, Aubrey Storey ${ }^{2}$, Aoife Osborne ${ }^{3}$, Caitriona Cunningham ${ }^{4} \mathbb{D}^{\text {, }}$ \\ Catherine Blake $^{4}\left(\mathbb{D}\right.$ and John McNamara ${ }^{4,5}$ \\ 1 National Centre for Men's Health, Institute of Technology Carlow, R93 V960 Carlow, Ireland; \\ diana.vandoorn@itcarlow.ie \\ 2 Department of Exercise and Health Science, Waterford Institute of Technology, X91 K0EK Waterford, Ireland; \\ astory@wit.ie \\ 3 School of Agriculture and Food Science, University College Dublin, D04 V1W8 Dublin, Ireland; \\ aoifeosborne@gmail.com \\ 4 School of Public Health, Physiotherapy \& Sports Science, University College Dublin, \\ D04 V1W8 Dublin, Ireland; caitriona.g.cunningham@ucd.ie (C.C.); c.blake@ucd.ie (C.B.); \\ john.g.mcnamara@teagasc.ie (J.M.) \\ 5 Teagasc-Agriculture and Food Development Authority, Kildalton, E32 YT92 Kilkenny, Ireland \\ * Correspondence: noel.richardson@itcarlow.ie
}

Citation: van Doorn, D.; Richardson

N.; Storey, A.; Osborne, A.;

Cunningham, C.; Blake, C.

McNamara, J. Investigating the Dietary Habits of Male Irish Farmers to Prevent Mortality and Morbidity. Safety 2021, 7, 54. https://doi.org/ $10.3390 /$ safety7030054

Academic Editor: Raphael Grzebieta

Received: 17 March 2021

Accepted: 13 July 2021

Published: 16 July 2021

Publisher's Note: MDPI stays neutral with regard to jurisdictional claims in published maps and institutional affiliations.

Copyright: (c) 2021 by the authors. Licensee MDPI, Basel, Switzerland. This article is an open access article distributed under the terms and conditions of the Creative Commons Attribution (CC BY) license (https:// creativecommons.org/licenses/by/ $4.0 /)$.

\begin{abstract}
Excess mortality and morbidity among Irish farmers from non-communicable diseases (NCDs) has been linked to a range of occupational risk factors. Obesity is a key risk factor underpinning this excess burden and unhealthy eating habits are linked to overweight/obesity and to disease occurrence. This study investigated the dietary habits of a sub-group of Irish male farmers and explored how these might potentially impact on health outcomes. Cross-sectional survey research was undertaken using self-reported quantitative data, based on convenience sampling and a 24-h food re-call survey. Data were analysed using frequency and chi-square analysis. Where possible, findings were compared to national survey data for Irish males. Findings revealed that a high proportion of farmers were overweight or obese and that dietary habits consisted of low intake of fruit, vegetables, and dairy and a high intake of meat, fried and processed foods, salt, and sugary and/or salty snacks. Younger farmers reported a significantly higher intake of processed meats; however, no associations were found between age, lifestyle behaviours, and dietary habits. The findings provide a greater understanding of how dietary habits potentially contribute to poorer health outcomes among farmers and underline the need for health promotion interventions, including healthy eating campaigns, aimed at farmers.
\end{abstract}

Keywords: farmers; dietary habits; gender; mortality; morbidity; occupational diseases; noncommunicable diseases; OSH; overweight/obesity; Total Worker Health

\section{Introduction}

The 'Total Worker Health' (TWH,®, (TWH is a registered programme of National Institute of Occupational Safety and Health (NIOSH), USA)) approach encapsulates a broad focus on wellness and wellbeing in conjunction with occupational safety and health (OSH) [1]. Within TWH, the workplace is considered a social determinant of health in so far as work-related factors can contribute to health outcomes. The approach adopts an integrated focus on research and the promotion of 'best practice' approaches that address health risks emerging from both the work environment and individual behaviours [1] Irish farmers are at high risk for mortality [2] and morbidity [3,4] from injury and noncommunicable diseases such as cardiovascular disease (CVD) and cancers. Being overweight/obese is now a major public health issue worldwide [5] and a recognized risk factor for non-communicable diseases such as CVD and certain cancers [6] and more recently for COVID-19 disease severity [7,8]. Both Irish $[9,10]$ and Australian $[11,12]$ studies have 
shown that an accumulation of risk factors for CVD, particularly overweight/obesity (Body Mass Index (BMI) of $\geq 25 \mathrm{~kg} / \mathrm{m}^{2}$ (overweight) or $\geq 30 \mathrm{~kg} / \mathrm{m}^{2}$ (obese) [13], is also high among farmers. Farming is also widely recognized as a hazardous occupation, due to a high prevalence of occupational injuries and fatalities and attention has been drawn to overweight/obesity as a confounding risk factor for occupational injury [14], musculoskeletal disorders (MSDs) [15], and depression [16,17]. Thus, from a TWH perspective, an examination of farmers dietary habits is warranted to seek to reduce the burden of mortality and morbidity associated with being overweight/obese. Although the aetiology of overweight/obesity is complex, it is well-established that unhealthy dietary habits are an important cause [18]; specifically an increased consumption of energy-dense food high in fat and sugars [19]. Additionally, a diet that includes a high usage of salt and low intake of vegetables and fruits is associated with CVD and certain cancers [20]. Reducing daily consumption of saturated fat, sugar, and salt, and increasing daily intake of fruit and vegetables are key targets in Ireland's National Health Policy [21].

There are clear sex differences in the aetiology of overweight/obesity and dietary habits more generally. In developed countries, the prevalence of overweight/obesity is higher in men than in women [18]. For example, in Ireland, more men are overweight/obese $(43 \% / 25 \%)$ than women $(31 \% / 22 \%)$ [22]; a pattern that is consistent across the European Union [23,24]. The WHO forecasts that by 2030, $89 \%$ of Irish men will be overweight, of whom $48 \%$ will be obese [5]. Men are more likely than women to accumulate adipose tissue in the trunk/abdomen $[25,26]$, and this 'abdominal obesity' is now considered as or more important than overall obesity in the evaluation of coronary heart disease (CHD) and CVD risk $[25,27]$ and diabetes type 2 [28]. It has also been shown that men's diets are generally less healthy than women's diets, with men tending to eat more meat, fried foods, and high-caloric items and less fruit and vegetables than women [29].

Farmers in Ireland are predominantly male, self-employed, from lower socio-economic groups, live in more rural isolated areas, and generally have lower educational attainment [30]. Based on these characteristics, male farmers have traditionally been regarded as 'hard-to-reach' with health interventions. To date, little is known about the dietary habits of Irish farmers. This study addresses a significant gap in the research by exploring the dietary habits of a sub-group of Irish farmers and examining how these dietary habits might potentially impact health outcomes. Focusing on the dietary habits of Irish farmers is justified not only in light of the high mortality and morbidity rates among farmers from obesity-related conditions such as CVD and cancers, but also in relation to the growing obesity 'epidemic' more generally among the Irish male population and internationally. The study is also timely because ill-health directly negatively impacts farm business performance and farm income [3].

This exploratory study builds upon previous research into the self-reported health status of Irish farmers [31], which also included survey questions examining farmers' food intake in the past $24 \mathrm{~h}$. The study objectives were to (1) explore associations between body composition and farmers' perceptions of their weight; (2) examine the dietary habits of farmers in the context of recommended national dietary guidelines [32]; and (3) explore associations between age and lifestyle behaviours (smoking, alcohol consumption, physical activity) on the one hand and BMI and reported dietary intake on the other.

\section{Methods}

\subsection{Ethics}

The study was reviewed and approved by the Ethics Committee of Waterford Institute of Technology (Ref 12HSES07, dated 5 February 2013) in Ireland. The research information sheet was attached to the questionnaire, which was handed out to all farmers. The questionnaire was completed anonymously and the act of completing the questionnaire was taken as consent. Participation was voluntary and farmers could decline participation by not filling in the questionnaire. 


\subsection{Sampling and Data Collection}

Convenience sampling was used to recruit male farmers $\geq 18$ years $(n=314)$ who attended either an advisory meeting or training course from Teagasc (Irish Agriculture and Food Development Authority) or a farmer organization meeting between March and August 2013 in the South-East of Ireland. Quantitative data were gathered using a questionnaire modelled on a validated Irish health survey instrument [33]. The questionnaire included several health sections including body composition (self-reported height and weight) and food intake. Although this national health survey used both 24-h recall variables and the Food Frequency Questionnaire [33,34], our study opted to make use of the 24-h food recall variables to gain insight into the dietary habits of farmers. This was a pragmatic choice: a 24 -h recall instrument requires only short-term memory and therefore was perceived as less of a time burden for the participants who already had been administered a comprehensive health questionnaire. Variables included a multiple response question, which asked participants to recall what they had for breakfast, light meal, and dinner the previous day. This short-term tool records more detailed information about dietary intake the previous day compared to long-term instruments which track dietary behaviour over a longer period [35]. Although used as a one-time measurement, the types of foods consumed by farmers the previous day were assumed to mirror their average daily intake of those foods. Participants were asked how often they typically consumed certain foods (snacks including the type of snack, salty foods, fried foods), while for this study specifically added questions queried the frequency of poultry, red meat, processed meat, and (oily) fish consumption. The questionnaire also included questions on the type of dairy products consumed, fats used for cooking and spreads, and the use of salt during cooking and at meal-times.

\subsection{Data Analysis}

Self-reported perception of body weight ('about the right weight', 'too heavy', 'too light' and 'not sure') was recorded. Body Mass Index (BMI) was calculated based on self-reported height and weight (weight in kilograms divided by the square of the person's height in meters $\left(\mathrm{kg} / \mathrm{m}^{2}\right)$. Analysis of reported foods consumed was based on national Irish food pyramid guidelines 'Food for Life' [32], which comprises six food categories: (1) fruit and vegetables (five-seven daily servings); (2) whole meal carbohydrates (bread, cereals, potatoes, pasta, and rice) three-five daily servings; (3) dairy (any three daily servings of milk, yoghurt, and cheese); (4) protein (any two daily servings of meat, poultry, fish, eggs, beans, and nuts); (5) fats (in very small amounts) and (6) sugary and/or salty snacks (max one or two per week). Data obtained were dependent on participants' self-reported responses and some questions were left unanswered. Results were calculated therefore on the available responses for each question. Results of the variables were regrouped based on the 'Food for Life' categories. This re-grouping included the reported servings from all variables included in the survey. For example: the reporting of fruit in the 'snack' variable was added to the food group 'fruit and vegetable'; yoghurt was added to 'dairy', and so on. Mean servings were derived from the total of servings per food category. For analysis purposes, food consumed in the first four food groups was broken down into three categories: below recommended/recommended/above recommended thresholds based on the 'Food for Life' recommendations: (1) fruit and vegetables $(0-4 / 5-7 / \geq 8)$; (2) carbohydrates $(0-2 / 3-5 / \geq 6) ;(3)$ dairy $(0-2 / 3 / \geq 4)$; (4) protein $(0-1 / 2 / \geq 3)$. The fifth category (fats) was broken into two categories (recommended/above recommended): (5) fats $(0-1 / \geq 2)$ : and the final category, sugary and/or salty snacks $(0-1 / \geq 2)$. Summary statistics were calculated mainly by frequencies and mean intake per food group category. Where possible farmers' dietary habits were compared to national survey data. Finally, chi square analysis was used to explore associations between age $(<45 / 45-64 / \geq 65)$, lifestyle behaviours (smoking $(\mathrm{y} / \mathrm{n})$, weekly alcohol consumption $(\mathrm{y} / \mathrm{n})$, weekly binge drinking $(\mathrm{y} / \mathrm{n})$, physical activity ( $\geq 5$ days per week moderate physically active $\mathrm{y} / \mathrm{n})$, and BMI $\mathrm{kg} / \mathrm{m}^{2}$ $(\leq 24.9 / 25.0-29.9 / \geq 30.0)$. This study investigated associations between these variables and 
the frequency of consumption of poultry, red meat, processed meat, and fish consumption (most days of the week/once or twice per week/never).

\section{Results}

As previously described [31], socio-demographic information showed that the mean age was 41.07 years (Table 1$)$. Two-thirds $(68 \% ; n=205)$ of farmers reported as being in full-time farming and engaged in a variety of farm enterprises: beef cattle/breeding cows $(31 \% ; n=98)$, dairy and beef cattle $(27 \% ; n=86)$, sheep $(25 \% ; n=81)$, mainly beef cattle $(19 \% ; n=59)$, intensive dairy $(17 \% ; n=54)$, and other including tillage $(19 \% ; n=60)$. Two-thirds $(64 \% ; n=198)$ also reported a farm size $>40.5$ Hectares. One in five farmers reported smoking $(20 \% ; n=57)$ and drinking alcohol one or more times weekly $(22 \%$; $n=65)$. The majority $(93 \% ; n=178)$ reported being moderately/highly physically active (Table 1).

Table 1. Socio-demographic and farm characteristics.

\begin{tabular}{|c|c|}
\hline Age $(n=302)$ & $n(\%)$ \\
\hline \multicolumn{2}{|l|}{ Mean age 41.07 SD 14.014} \\
\hline$<45$ & $179(59)$ \\
\hline $45-64$ & $105(35)$ \\
\hline$\geq 65$ & $18(6)$ \\
\hline \multicolumn{2}{|l|}{ Smoking } \\
\hline \multicolumn{2}{|l|}{ Do you currently smoke? $(n=288)$} \\
\hline Yes & $57(20)$ \\
\hline No & $231(80)$ \\
\hline \multicolumn{2}{|l|}{ Alcohol consumption } \\
\hline \multicolumn{2}{|l|}{ How often do you drink alcohol $(n=292)$} \\
\hline One or more times per week & $65(22)$ \\
\hline One or more times per month & $119(41)$ \\
\hline On occasion & $72(25)$ \\
\hline Never & $36(12)$ \\
\hline \multicolumn{2}{|c|}{ How often do you have 6 or more standard drinks on one occasion $*(n=255)$} \\
\hline One or more times per week & $55(22)$ \\
\hline One or more times per month & $72(28)$ \\
\hline Less often & $90(35)$ \\
\hline Never & $38(15)$ \\
\hline \multicolumn{2}{|l|}{ Physical activity } \\
\hline \multicolumn{2}{|l|}{ Are you physically active in your work $(n=306)$} \\
\hline Very physically active & $85(28)$ \\
\hline Fairly physically active & $188(61)$ \\
\hline Slightly physically active & $26(9)$ \\
\hline Not physically active at all & $7(2)$ \\
\hline \multicolumn{2}{|l|}{ Levels of physical activity $(n=257)$} \\
\hline Low & $17(7)$ \\
\hline Moderate & $72(28)$ \\
\hline High & $168(65)$ \\
\hline
\end{tabular}

\subsection{Body Composition}

Based on BMI classifications, almost two-thirds $(62 \% ; n=185)$ of farmers were overweight or obese (Table 2). Two-thirds $(65 \% ; n=200)$ also reported being 'about the right weight' while $25 \%(n=78)$ reported being 'too heavy'. Indeed, half of farmers $(53 \% ; n=102)$ who reported being 'about the right weight' were, based on BMI calculations, classified as overweight or obese. One in seven farmers $(15 \% ; n=45)$ reported having been told by their doctor in the previous 12 months to lose weight, whilst one-third $(31 \% ; n=94)$ reported having actively tried to lose weight in the past 12 months. 
Table 2. Body Weight and Weight Loss Behaviours.

\begin{tabular}{|c|c|c|c|}
\hline \multicolumn{3}{|c|}{ Perception of Weight $(n=310)$} & $n(\%)$ \\
\hline \multicolumn{3}{|c|}{ Right Weight } & $200(65)$ \\
\hline \multicolumn{3}{|c|}{ Too Heavy } & $78(25)$ \\
\hline \multicolumn{3}{|c|}{ Too Light } & $16(5)$ \\
\hline \multicolumn{3}{|c|}{ Not Sure } & $16(5)$ \\
\hline \multicolumn{4}{|c|}{ BMI based on Self-Reported Weight and Height $(n=297)$} \\
\hline \multicolumn{3}{|c|}{$<18.5^{\prime}$ Underweight’ } & $0(0)$ \\
\hline \multicolumn{3}{|c|}{$\leq 24.9$ 'Normal Weight' } & $112(38)$ \\
\hline \multicolumn{3}{|c|}{ 25.0-29.9 'Overweight' } & $138(46)$ \\
\hline \multicolumn{3}{|c|}{$\geq 30.0$ 'Obese' $^{\prime}$} & $47(16)$ \\
\hline \multirow{2}{*}{\multicolumn{4}{|c|}{$\begin{array}{l}\text { Perception of Own Weight and BMI Classification; Based on Self-Reported Height and } \\
\text { Weight }(n=296) \\
\text { BMI Classification }\end{array}$}} \\
\hline & & & \\
\hline \multirow[t]{2}{*}{$\begin{array}{c}\text { Perception of Own } \\
\text { Weight }\end{array}$} & $\mathrm{BMI} \leq 24.9$ & BMI 25.0-29.9 & $\mathrm{BMI} \geq 30.0$ \\
\hline & $n=112$ & $n=137$ & $n=47$ \\
\hline $\begin{array}{l}\text { About the Right } \\
\text { Weight }(n=193)\end{array}$ & $91(47)$ & $95(49)$ & $7(4)$ \\
\hline Too Heavy $(n=73)$ & $2(3)$ & $34(46)$ & $37(51)$ \\
\hline Too Light $(n=15)$ & $15(100)$ & $0(0)$ & $0(0)$ \\
\hline Not Sure $(n=15)$ & $4(27)$ & $8(53)$ & $3(20)$ \\
\hline \multicolumn{3}{|c|}{ Told by Doctor to Lose Weight in the Last 12 Months $(n=307)$} & $n(\%)$ \\
\hline \multicolumn{3}{|c|}{ Yes } & $45(15)$ \\
\hline \multicolumn{3}{|c|}{ No } & $262(85)$ \\
\hline \multicolumn{3}{|c|}{ Actively Tried to Lose Weight in the Last 12 Months $(n=307)$} & $n(\%)$ \\
\hline \multicolumn{3}{|c|}{ Yes } & $94(31)$ \\
\hline \multicolumn{3}{|c|}{ No } & $213(69)$ \\
\hline
\end{tabular}

\subsection{Dietary Habits Compared to National 'Food for Life' Guidelines}

A review of reported daily intake of food groups relative to the Irish food pyramid guidelines (Table 3 ) highlights that the vast majority of farmers $(94 \% ; n=275)$ reported eating less than the recommended five portions of fruit and/or vegetables per day, twothirds $(67 \% ; n=200)$ less than the recommended three servings of dairy products per day, one in four $(24 \% ; n=71)$ more than the recommended two servings of protein per day, while one in $10(11 \% ; n=33)$ reported consuming $\geq 2$ servings of fats per day. Over half of farmers $(60 \% ; n=181)$ reported having eaten sugary and/or salty snacks between meals the previous day, the majority $(72 \% ; n=140)$ of whom reported eating two or more sugary and / or salty snacks. This compares to $35 \%$ (not gender specified) from national survey data who reported consumption of one or more sugary and/or salty snacks per day.

Table 3. Daily Intake of Food Groups Compared to the Healthy Food for Life Guidelines.

\begin{tabular}{cc}
\hline Vegetables and Fruit Servings $-\geq$ Daily Servings Recommended $(\boldsymbol{n = 2 9 2 )}$ & $\boldsymbol{n} \mathbf{( \% )}$ \\
\hline Mean Number of Servings 1.77-SD 1.580 & $70(23)$ \\
0 & $205(71)$ \\
$5-4$ & $15(5)$ \\
$\geq 8$ & $2(1)$ \\
\hline Carbohydrates Servings-3-5 Daily Servings Recommended $(\boldsymbol{n}=\mathbf{2 9 6 )}$ & $\boldsymbol{n ( \% )}$ \\
Mean 3.65-SD 1.899 & $78(26)$ \\
$0-2$ & $171(58)$ \\
$3-5$ & $47(16)$ \\
\hline
\end{tabular}


Table 3. Cont.

\begin{tabular}{|c|c|}
\hline \multicolumn{2}{|l|}{ Mean 2.25—SD 1.379} \\
\hline $0-2$ & $200(67)$ \\
\hline 3 & $47(16)$ \\
\hline$\geq 4$ & $49(17)$ \\
\hline Mean $1.89-S D 1.088$ & $n(\%)$ \\
\hline $0-1$ & $110(37)$ \\
\hline 2 & $114(39)$ \\
\hline$\geq 3$ & $71(24)$ \\
\hline Fats Servings-Few as Possible (Quantified as 0-1) $(n=296)$ & $n(\%)$ \\
\hline \multicolumn{2}{|l|}{ Mean 0.59—SD 0.931} \\
\hline $0-1$ & $263(89)$ \\
\hline$\geq 2$ & $33(11)$ \\
\hline Did You Eat Sugary and/or Salty Snacks Between Meals Yesterday? $(n=303)$ & $n(\%)$ \\
\hline Yes & $181(60)$ \\
\hline No & $122(40)$ \\
\hline How Many Sugary and/or Salty Snacks? $(n=180)$ & $n(\%)$ \\
\hline \multicolumn{2}{|l|}{ Mean 2.15-SD 1.031} \\
\hline 1 & $40(28)$ \\
\hline $2-6$ & $140(72)$ \\
\hline
\end{tabular}

\subsection{Eating and Cooking Habits}

Findings in relation to eating and cooking habits showed that more than half of farmers $(60 \% ; n=182)$ reported consuming fried food more than once per week (Table 4$)$. The majority of farmers $(71 \% ; n=217)$ reported consumption of full fat milk rather than low fat. More than one in three reported that salt was added during cooking $(35 \% ; n=106)$ and/or to food at meal-times $(36 \% ; n=108)$. Interestingly, those who reported adding salt during cooking were significantly more likely to add salt at meal-times $(p=<0.001)$. Almost half of farmers $(46 \% ; n=131)$ reported consuming red meat most days of the week whilst one in six farmers $(17 \% ; n=44)$ reported consuming processed meats most days of the week (Table 5). Chi square analysis showed that younger farmers $(<45$ years) were significantly more likely to report consumption of processed meats $(p=0.014)$ and poultry ( $p=0.001)$ on most days of the week. No significant associations were found between age and the daily recommended servings of vegetables, carbohydrates, dairy, or fats, nor in the frequency of consumption of red meat and fish. No significant associations were found between adverse lifestyle behaviours (smoking $\mathrm{y} / \mathrm{n}$, alcohol consumption $\mathrm{y} / \mathrm{n}$, weekly 'binge' drinking $\mathrm{y} / \mathrm{n}$, being moderately physically active on $\geq 5$ days per week $\mathrm{y} / \mathrm{n}$ ) and body weight (BMI $\leq 24.9 / 25.0-29.9 / \geq 30.0$ ) on the one hand, and not meeting the 'Food for Life' dietary guidelines in relation to the daily recommended servings of vegetables, carbohydrates, dairy, fats and the frequency of the consumption of poultry, red meat, processed meat, and (oily) fish, on the other.

Table 4. Eating and Cooking Habits.

\begin{tabular}{cc}
\hline Yesterday, I Did Not Have: & $\boldsymbol{n ( \% )}$ \\
\hline Breakfast $(n=285)$ & $30(11)$ \\
Light Meal (Lunch, Supper $(n=300)$ & $15(5)$ \\
Heavy Meal (Dinner) $(n=298)$ & $17(6)$ \\
\hline Fried Food Intake $(n=302)$ & $48(16)$ \\
$>4$ Times a Week & $134(44)$ \\
$1-3$ Times a Week & $120(40)$ \\
\hline 1 Time a Week &
\end{tabular}


Table 4. Cont.

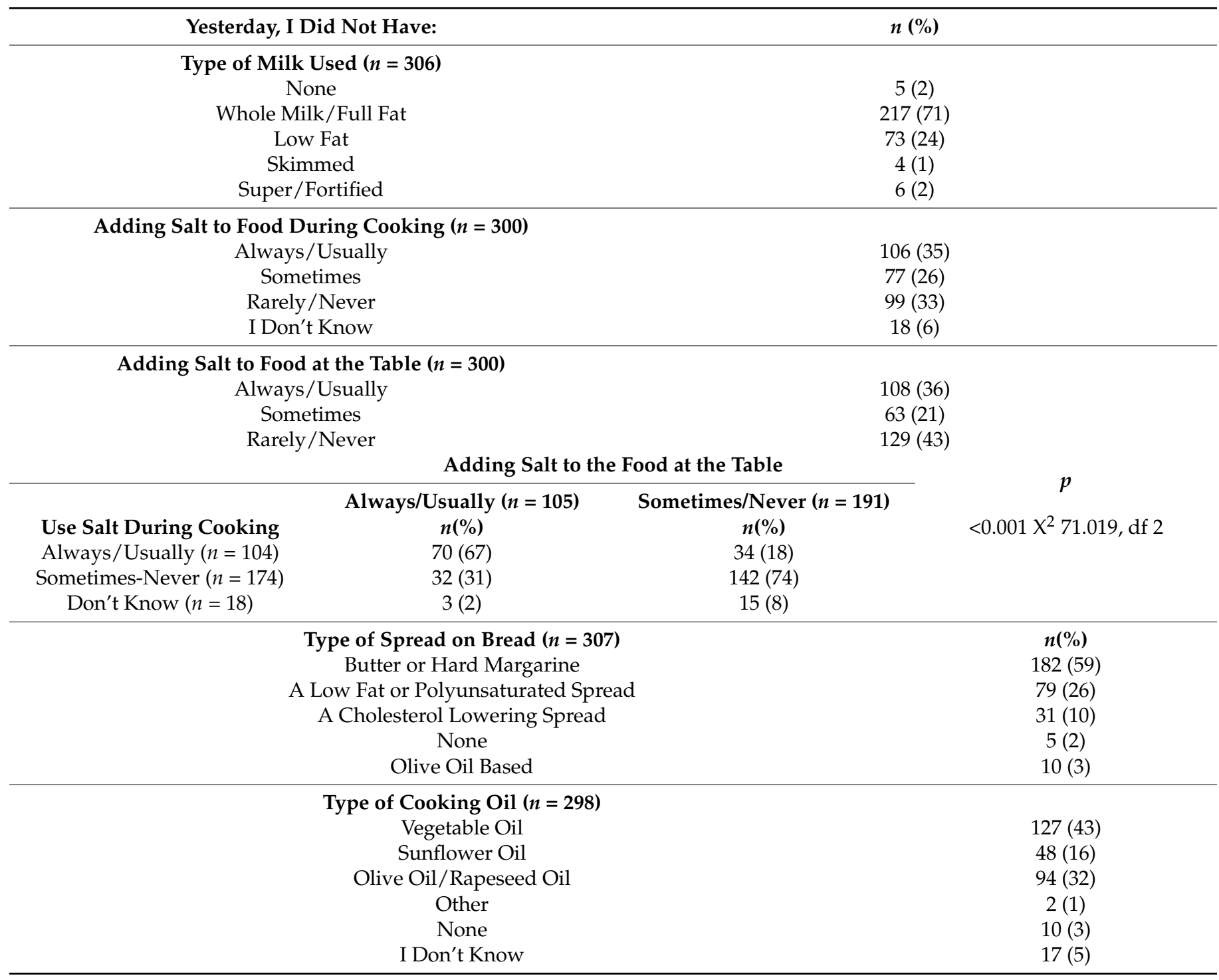

Table 5. Meat and fish consumption.

\begin{tabular}{|c|c|c|c|c|c|}
\hline $\begin{array}{l}\text { How Often Do You Eat } \\
\text { the Following Meats }\end{array}$ & $\begin{array}{c}\text { Poultry }(n=283) \\
n(\%)\end{array}$ & $\begin{array}{c}\text { Red Meat } \\
(n=282) \\
n(\%)\end{array}$ & $\begin{array}{c}\text { Fish }(n=239) \\
n(\%)\end{array}$ & $\begin{array}{c}\text { Oily Fish } \\
(n=172) \\
n(\%)\end{array}$ & $\begin{array}{c}\text { Processed Meats } \\
\quad(n=259) \\
n(\%)\end{array}$ \\
\hline Never & $4(1)$ & $2(1)$ & $22(9)$ & $43(25)$ & $11(4)$ \\
\hline Less Than Once a Week & $37(14)$ & $12(4)$ & $93(39)$ & $70(41)$ & $58(23)$ \\
\hline Once or Twice a Week & $213(75)$ & $137(49)$ & $117(49)$ & $51(30)$ & $146(56)$ \\
\hline Most Days of the Week & $29(10)$ & $131(46)$ & $7(3)$ & $8(4)$ & $44(17)$ \\
\hline Age & $\begin{array}{c}<45 \\
(n=160)\end{array}$ & $\begin{array}{c}45-64 \\
(n=97)\end{array}$ & $\begin{array}{c}\geq 65 \\
(n=15)\end{array}$ & \multicolumn{2}{|c|}{$p$} \\
\hline Poultry & & & & \multirow{2}{*}{\multicolumn{2}{|c|}{$0.001 \mathrm{X}^{2} 14.99 \mathrm{df} 2$}} \\
\hline $\begin{array}{c}\text { Never-Max } 2 \text { Per Week } \\
\qquad(n=222)\end{array}$ & $134(83.7)$ & $95(97.9)$ & $15(100.0)$ & & \\
\hline $\begin{array}{l}\text { Most Days of the Week } \\
\qquad(n=28)\end{array}$ & $26(16.3)$ & $2(2.1)$ & $0(0.0)$ & & \\
\hline
\end{tabular}


Table 5. Cont.

\begin{tabular}{ccccc}
\hline Age & $\begin{array}{c}<5 \\
(n=\mathbf{1 5 4})\end{array}$ & $\begin{array}{c}\mathbf{4 5 - 6 4} \\
(\boldsymbol{n}=\mathbf{8 3})\end{array}$ & $\begin{array}{c}\geq \mathbf{6 5} \\
(\boldsymbol{n}=\mathbf{1 3})\end{array}$ & $\begin{array}{c}\boldsymbol{p} \\
\text { Processed meats }\end{array}$ \\
$\begin{array}{c}\text { Never-Max 2 per Week } \\
\text { Most days of the Week }\end{array}$ & $119(77.3)$ & $76(91.6)$ & $12(92.3)$ & $1(7.7)$ \\
\hline
\end{tabular}

\section{Discussion}

This study investigated body composition, perception of weight, and the dietary habits of a cohort of Irish farmers, and explored associations between these variables and age and lifestyle behaviours. Dietary habits were explored in the context of recommended national dietary guidelines. Results revealed that a high proportion of farmers were overweight or obese and that dietary habits consisted of a low intake of fruit and vegetables and dairy and a high intake of meat, fried foods, salt, and sugary and/or salty snacks. Findings provide a greater understanding of how dietary habits might potentially contribute to poorer health outcomes among farmers and underline the importance and urgency of developing effective and tailored health promotion interventions for farmers, including healthy eating campaigns as part of TWH interventions. The prevalence of overweight/obesity (62\%) among this sub-group of farmers is somewhat lower than national survey data $(68 \%)$ for Irish males [22]. This is most likely explained by the age profile of participants in this study, which comprised mostly younger farmers (mean age 41.07) compared to the national average age of 57 years among the farming workforce. It is well established that weight and body composition increase with age [36]. Nevertheless, this study found an anomaly between perception of weight and BMI scores: it transpired that more than half of those (53\%) who reported as being 'about the right weight' were, based on self-reported height and weight (and calculated BMI), actually classified as overweight or obese. Previous research findings have shown that men who are overweight/obese tend not to see their excess weight as a cause of concern until their weight has reached obesity proportions or has become associated with obesity-related co-morbidities [37,38]. Notably, a third of farmers reported having actively tried to lose weight in the past 12 months; however, findings also suggest that these farmers were either unsuccessful or failed to sustain weight loss.

Notwithstanding the limitation of BMI as a body composition measure in failing to distinguish between fat mass and lean body mass, dietary indicators such as high intake of red meat and fried foods, and snacking on sugary foods, are indicative of behaviours likely to be associated with being overweight or obese among this cohort of farmers. It is well established that even modest intentional weight loss can have a significant bearing on reducing CVD and cancer risk. For example, a waist reduction of 5-10 cm can result in improvements in several CVD risk factors [39], a 10\% loss of body weight can lead to one third decline of inflammatory (cancer) markers [40], and 5-10\% weight loss is associated with significantly reduced levels of blood glucose among those with diabetes type 2 [41]. Indeed, weight loss among those who are overweight/obese not only reduces CVD risk but is also likely to improve occupational health and safety as being overweight or obese is associated with increased risk of occupational farm injuries [14].

The concerns raised in this study about farmers' dietary habits are consistent with previous research which shows that men's diets are less healthy than women's diets, with men eating more than the recommended daily intake of protein, more fried foods and highcalorific items, and less fruit and vegetables than women [29,42,43]. Only a small minority of farmers $(6 \%)$ reported having consumed the recommended daily intake ( $\geq 5$ servings) of fruit and vegetables, well below that of national survey data of $21 \%$ among Irish males. Reported salt consumption was also high, with those farmers who reported that salt was added during cooking being significantly more likely to also report adding salt to food at meal-times. An unusual and novel finding was the low intake of fruit and vegetables in this cohort with almost one in four farmers reporting not having consumed any fruit or vegetable in the previous day. This warrants further investigation in future studies as low 
consumption of fruit and vegetables, and high salt intake are both associated with increased risk of CVD and certain cancers [20]. Interestingly, no associations were found between age, lifestyle behaviours, and dietary habits. This might be related to the younger age profile in this sample and further research with a more representative sample is recommended to explore possible associations between these variables.

One in six farmers reported daily consumption of processed meats, which as well as containing 'hidden' levels of salt, fats, and sugars, also increases risk of colon cancer [44]. One in three farmers reported consuming two or more sugary and/or salty snacks between meals, which leads to an increased risk of becoming overweight/obese, and in turn to an increased risk of chronic diseases. Younger farmers ( $<45$ years) reported a significantly higher consumption of processed meats, and although not significant, also reported a higher consumption of meat and starchy foods and fewer servings of fruit and vegetables. A qualitative study with English men reported a greater disregard for healthy eating among younger men and that older men were more likely to cite awareness of their vulnerability to disease and to take the health consequences of diet more seriously [45]. Within a gender and masculinities context, previous studies have found that, compared to women, men tend to be less knowledgeable about the health benefits of particular 'foodstuffs' [46], are less inclined to read food labels [47], and a large group of men tend to defer to women for guidance on food and dietary matters [45]. Men often regard healthy food as insubstantial and tend to be sceptical and cynical about healthy eating media campaigns $[45,48]$. These findings underline the importance of accounting for a gendered approach to healthy eating campaigns and health promotion interventions specifically aimed at rural men and farmers, and giving due regard to the rural socio-cultural context and the unique occupational characteristics of farming.

These study learnings show the complexity of health status among farmers and highlight the urgent need to integrate healthy eating and weight loss support into health promotion initiatives for farmers. Future TWH interventions and support networks should adopt an interdisciplinary approach and include agricultural industry stakeholders such as advisory and training programme delivery, farming organisation participation or support, and any other relevant partner organisations found to be the centre of a farmers' social network [49]. An interdisciplinary approach can broaden the reach among so called 'hardto-reach' farmers, enhance health promotion acceptability [50] and enhance knowledge translation and implementation [51]. In line with best TWH practice, many initiatives are possible including, the development and promotion of healthy food options in agricultural workplace settings, media promotion of healthy eating among farmers, inclusion of advice on dietary issues in training events, along with the raising of dietary and weight control issues by medical doctors in consultations with farmers.

\section{Limitations and Strengths}

This study acknowledges some limitations. The 24-h re-call instrument used in this study does not allow for analysis of the nutrient content of consumed foods. In relation to the daily consumption of starchy foods, analysis did not distinguish between 'white' and 'whole meal' products. There was no distinction made between different serving sizes (small or large), thus all responses were counted as one average serving. On reflection, the questionnaire should have included a variable that explored farmers' knowledge of cooking and cooking behaviours. The study would have been strengthened by the inclusion of measurements on waist circumference, as the use of BMI as an indicator of overweight/obesity does not distinguish between fat mass and lean body mass. The non-probability sampling (convenience) means that the results may not be generalisable to the farming population as a whole. The socio-demographics of this study population are not representative of the national average of Irish famers [31]. Farmers with greater health problems are unlikely to be captured in the study ('healthy worker' effect). Self-report measures rely on participants providing honest and reliable responses and should therefore be treated with caution. Despite these limitations, this study does provide important 
insights into the high prevalence of overweight/obesity and the high consumption of 'high risk' foods among a subset of Irish farmers.

\section{Conclusions}

This exploratory paper reported survey findings on farmers' dietary habits in the previous 24-h. Despite growing concerns about the prevalence of obesity among farmers, there has, to date, been a dearth of research into the dietary patterns of Irish male farmers. Notwithstanding some study limitations, the learnings from this study are informative and novel, and can provide leverage for action to promote healthy eating among farmers. The study identified a high incidence of overweightness/obesity and associated poor dietary habits among this sample of Irish farmers. This is an important finding as Irish studies on farmers' health have identified high levels of mortality and morbidity, including injury occurrence and MSDs, with farmer weight and diet being among the possible contributory factors. Findings also suggest that farmers tend to have a largely meat-based diet, high in salt, fats, and sugar but low in fruit and vegetables. The study findings underline the need for targeted, interdisciplinary, and on-going supports for farmers in their efforts to lose weight and to sustain weight loss as well as to promote increased awareness of what constitutes healthy eating. Additionally, despite being perceived to be 'hard-toreach', findings from a workplace health screening intervention for farmers in Ireland have shown that, with the right approach, farmers will engage with health programmes [52] indicating that the workplace could be an effective setting to reach farmers with health promotion. The TWH approach [1], also offers potential synergies between OSH and health promotion, including a potential focus on weight loss and healthy eating for farmers in extension programmes.

Author Contributions: Conceptualization, A.S. and J.M.; methodology, A.S. and J.M.; Survey collection, A.S. and J.M.; formal analysis, A.O., C.B., and D.v.D.; writing-original draft preparation, D.v.D. and N.R; writing-review and editing, C.B., C.C., D.v.D., and N.R.; supervision, A.S. and N.R.; project administration, D.v.D., J.M., and N.R.; funding acquisition, A.S., J.M., N.R. All authors have read and agreed to the published version of the manuscript.

Funding: No grant was obtained for this research. This research was funded by the resources and work time provided by the authors' institutions.

Institutional Review Board Statement: The study was conducted according to the research guidelines of the authors' institutions and approved by the Ethics Committee of Waterford Institute of Technology (Ref 12HSES07) in Ireland.

Informed Consent Statement: Implied informed consent was obtained from all subjects involved in the study.

Data Availability Statement: Data available on request due to ethical restrictions. The data presented in this study are available on request from the corresponding author. The data are not publicly available due to the specifications of our data storage in our ethics application.

Acknowledgments: The authors would like to thank participating farmers and staff of Teagasc and Officers of IFA for facilitating data collection. Bríd McNamara is thanked for inputting data into IT and checking it.

Conflicts of Interest: The authors declare no conflict of interest. Each author had academic freedom related to the Manuscript preparation.

\section{References}

1. Anger, W.K.; Elliot, D.L.; Bodner, T.; Olson, R.; Rohlman, D.; Truxillo, D.M.; Kuehl, K.S.; Hammer, L.B.; Montgomery, D. Effectiveness of Total Worker Health interventions. J. Occup. Health Psychol. 2015, 20, 226-247. [CrossRef] [PubMed]

2. Smyth, B.; Evans, D.S.; Kelly, A.; Cullen, L.; O'Donovan, D. The farming population in Ireland: Mortality trends during the 'Celtic Tiger' years. Eur. J. Public Health 2013, 23, 50-55. [CrossRef] [PubMed]

3. Whelan, S.; Ruane, D.J.; McNamara, J.; Kinsella, A.; McNamara, A. Disability on Irish Farms—A Real Concern. J. Agromed. 2009, 14, 157-163. [CrossRef] [PubMed] 
4. McNamara, J.; Ruane, D.J.; Whelan, S.; Connolly, L. Preliminary Investigation of the Incidence and Impact of Disability on Irish Farms Preliminary Investigation of the Incidence and Impact of Disability on Irish. J. Int. Agric. Ext. Educ. 2007, 14, 21-33.

5. World Health Organization. Global Status Report on Noncommunicable Diseases 2014; World Health Organization: Geneva, Switzerland, 2014.

6. World Health Organization. Fact Sheet. Obesity and Overweight. Available online: https://www.who.int/news-room/factsheets/detail/obesity-and-overweight (accessed on 16 April 2020).

7. Petrakis, D.; Margină, D.; Tsarouhas, K.; Tekos, F.; Stan, M.; Nikitovic, D.; Kouretas, D.; Spandidos, D.A.; Tsatsakis, A. Obesity-a risk factor for increased COVID-19 prevalence, severity and lethality. Mol. Med. Rep. 2020, 22, 9-19. [CrossRef] [PubMed]

8. Dietz, W.; Santos-Burgoa, C. Obesity and its Implications for COVID-19 Mortality. Obesity 2020, 28, 1005. [CrossRef] [PubMed]

9. van Doorn, D.; Richardson, N.; Osborne, A. Farmers Have Hearts: The prevalence of risk factors for cardiovascular disease among a sub-group of Irish livestock farmers. J. Agromed. 2017, 22, 264-274. [CrossRef]

10. van Doorn, D.; Richardson, N.; Meredith, D.; McNamara, J.; Osborne, A.; Blake, C. Farmers Have Hearts Cardiovascular Health Programme. Detailed Baseline Report; Teagasc, National Centre for Men's Health at IT Carlow: Carlow, Ireland, 2020.

11. Brumby, S.; Kennedy, A.; Chandrasekara, A. Alcohol Consumption, Obesity, and Psychological Distress in Farming CommunitiesAn Australian Study. J. Rural Health 2013, 29, 311-319. [CrossRef]

12. Brumby, S.; Chandrasekara, A.; McCoombe, S.; Kremer, P.; Lewandowski, P. Cardiovascular risk factors and psychological distress in Australian farming communities. Aust. J. Rural Health 2012, 20, 131-137. [CrossRef] [PubMed]

13. World Health Organization. Body Mass Index-BMI. Available online: http://www.euro.who.int/en/health-topics/diseaseprevention/nutrition/a-healthy-lifestyle/body-mass-index-bmi (accessed on 16 April 2020).

14. King, N.; Janssen, I.; Hagel, L.; Dosman, J.; Lawson, J.; Trask, C.; Pickett, W.; Saskatchewan Farm Injury Study Team. Identifying and mitigating risks for agricultural injury associated with obesity. Prev. Med. Rep. 2016, 4, 220-224. [CrossRef]

15. Wearing, S.C.; Hennig, E.M.; Byrne, N.M.; Steele, J.R.; Hills, A.P. Musculoskeletal disorders associated with obesity: A biomechanical perspective. Obes. Rev. 2006, 7, 239-250. [CrossRef]

16. Luppino, F.S.; de Wit, L.M.; Bouvy, P.F.; Stijnen, T.; Cuijpers, P.; Penninx, B.W.; Zitman, F.G. Overweight, obesity, and depression: A systematic review and meta-analysis of longitudinal studies. Arch. Gen. Psychiatry 2010, 67, 220-229. [CrossRef] [PubMed]

17. Roberts, R.E.; Deleger, S.; Strawbridge, W.J.; Kaplan, G.A. Prospective association between obesity and depression: Evidence from the Alameda County Study. Int. J. Obes. 2003, 27, 514-521. [CrossRef]

18. Kanter, R.; Caballero, B. Global gender disparities in obesity: A review. Adv. Nutr. 2012, 3, 491-498. [CrossRef]

19. World Health Organization. Healthy Diet. Key Facts. Available online: https://www.who.int/en/news-room/fact-sheets/ detail/healthy-diet (accessed on 16 April 2020).

20. Aune, D.; Giovannucci, E.; Boffetta, P.; Fadnes, L.T.; Keum, N.; Norat, T.; Greenwood, D.C.; Riboli, E.; Vatten, L.J.; Tonstad, S. Fruit and vegetable intake and the risk of cardiovascular disease, total cancer and all-cause mortality-a systematic review and dose-response meta-analysis of prospective studies. Int. J. Epidemiol. 2017, 46, 1029-1056. [CrossRef]

21. Department of Health. Healthy Ireland. A Framework for Improved Health and Wellbeing 2013-2025; Department of Health: Dublin, Ireland, 2013.

22. Department of Health. Healthy Ireland Summary Report 2019; Government Publications, Department of Health: Dublin, Ireland, 2019.

23. Marques, A.; Peralta, M.; Naia, A.; Loureiro, N.; De Matos, M.G. Prevalence of adult overweight and obesity in 20 European countries, 2014. Eur. J. Public Health 2018, 28, 295-300. [CrossRef]

24. Eurostat. Overweight and Obesity-BMI Statistics-Statistics Explained. Available online: https://ec.europa.eu/eurostat/statisticsexplained/index.php/Overweight_and_obesity_-_BMI_statistics\#Obesity_in_the_EU:_gender_differences (accessed on 16 February 2021).

25. Lumish, H.S.; O'Reilly, M.; Reilly, M.P. Sex Differences in Genomic Drivers of Adipose Distribution and Related Cardiometabolic Disorders. Arterioscler. Thromb. Vasc. Biol. 2020, 40, 45-60. [CrossRef] [PubMed]

26. Krotkiewski, M.; Björntorp, P.; Sjöström, L.; Smith, U. Impact of obesity on metabolism in men and women. Importance of regional adipose tissue distribution. J. Clin. Investig. 1983, 72, 1150-1162. [CrossRef] [PubMed]

27. Lakka, H.M.; Lakka, T.A.; Tuomilehto, J.; Salonen, J.T. Abdominal obesity is associated with increased risk of acute coronary events in men. Eur. Heart J. 2002, 23, 706-713. [CrossRef] [PubMed]

28. Freemantle, N.; Holmes, J.; Hockey, A.; Kumar, S. How strong is the association between abdominal obesity and the incidence of type 2 diabetes? Int. J. Clin. Pract. 2008, 62, 1391-1396. [CrossRef] [PubMed]

29. Prättälä, R.; Paalanen, L.; Grinberga, D.; Helasoja, V.; Kasmel, A.; Petkeviciene, J. Gender differences in the consumption of meat, fruit and vegetables are similar in Finland and the Baltic countries. Eur. J. Public Health 2007, 17, 520-525. [CrossRef]

30. Central Statistics Office. Farm Structure Survey 2016; Central Statistics Office: Dublin, Ireland, 2016.

31. van Doorn, D.; Richardson, N.; Storey, A.; Osborne, A.; Cunningham, C.; Blake, C.; McNamara, J. Farming characteristics and self-reported health outcomes of Irish farmers. Occup. Med. 2018, 68, 199-202. [CrossRef]

32. Health Service Executive. Healthy Food fo Life. The Food Pyramid. For Adults, Teenagers and Children Aged Five and Over; Health Service Executive: Dublin, Ireland, 2016.

33. Morgan, K.; McGee, H.; Watson, D.; Perry, I.; Barry, M.; Lente, V.E. Slan 2007: Survey of Lifestyle, Attitudes $\mathcal{E}$ Nutrition in Ireland: Main Report; The Stationery Office: Dublin, Ireland, 2008. 
34. Ward, M.; McGee, H.; Morgan, K.; Van Lente, E.; Layte, R.; Barry, M.; Watson, D.; Shelley, E.; Perry, I. SLÁN 2007: Survey of Lifestyle, Attitudes and Nutrition in Ireland. 'One Island-One Lifestyle?' Health and lifestyles in the Republic of Ireland and Northern Ireland: Comparing the Population Surveys SLÁN 2007 and NIHSWS 2005; Department of Health and Children: Dublin, Ireland, 2009.

35. Schatzkin, A.; Kipnis, V.; Carroll, R.J.; Midthune, D.; Subar, A.F.; Bingham, S.; Schoeller, D.A.; Troiano, R.P.; Freedman, L.S. A comparison of a food frequency questionnaire with a 24-hour recall for use in an epidemiological cohort study: Results from the biomarker-based Observing Protein and Energy Nutrition (OPEN) study. Int. J. Epidemiol. 2003, 32, 1054-1062. [CrossRef]

36. Stevens, J.; Katz, E.G.; Huxley, R.R. Associations between gender, age and waist circumference. Eur. J. Clin. Nutr. 2010, 64, 6-15. [CrossRef]

37. McCarthy, M.; Richardson, N.; Osborne, A.; Clarke, N. The Role of Primary Care: Men's Perspectives on Attempting to Lose Weight through a Community-based Dietician Service I McCarthy I New Male Studies. New Male Stud. Int. J. 2016, 5, 48-67.

38. Mc Pherson, K.E. Body Image Satisfaction in Men: Its implications for promoting health behaviours. In Proceedings of the Presentation at 5th National Men's Health Conference, Arlington, VI, USA, 20-22 May 2004.

39. de Koning, L.; Merchant, A.T.; Pogue, J.; Anand, S.S. Waist circumference and waist-to-hip ratio as predictors of cardiovascular events: Meta-regression analysis of prospective studies. Eur. Heart J. 2007, 28, 850-856. [CrossRef] [PubMed]

40. Byers, T.; Sedjo, R.L. Does intentional weight loss reduce cancer risk? Diabetes Obes. Metab. 2011, 13, 1063-1072. [CrossRef]

41. Wing, R.R.; Lang, W.; Wadden, T.A.; Safford, M.; Knowler, W.C.; Bertoni, A.G.; Hill, J.O.; Brancati, F.L.; Peters, A.; Wagenknecht, L. Benefits of Modest Weight Loss in Improving Cardiovascular Risk Factors in Overweight and Obese Individuals With Type 2 Diabetes. Diabetes Care 2011, 34, 1481-1486. [CrossRef]

42. White, A.; De Sousa, B.; De Visser, R.; Hogston, R.; Madsen, S.A.; Makara, P.; McKee, M.; Raine, G.; Richardson, N.; Clarke, N.; et al. Men's health in Europe. J. Men's Health 2011, 8, 192-201. [CrossRef]

43. Hartmann, C.; Siegrist, M.; van der Horst, K. Snack frequency: Associations with healthy and unhealthy food choices. Public Health Nutr. 2013, 16, 1487-1496. [CrossRef]

44. Bouvard, V.; Loomis, D.; Guyton, K.Z.; Grosse, Y.; El Ghissassi, F.; Benbrahim-Tallaa, L.; Guha, N.; Mattock, H.; Straif, K. Carcinogenicity of consumption of red and processed meat. Lancet Oncol. 2015, 16, 1599-1600. [CrossRef]

45. Gough, B.; Conner, M.T. Barriers to healthy eating amongst men: A qualitative analysis. Soc. Sci. Med. 2006, 62, 387-395. [CrossRef] [PubMed]

46. Kiefer, I.; Rathmanner, T.; Kunze, M. Eating and dieting differences in men and women. J. Men's Health Gend. $2005,2,194-201$. [CrossRef]

47. Satia, J.A.; Galanko, J.A.; Neuhouser, M.L. Food nutrition label use is associated with demographic, behavioral, and psychosocial factors and dietary intake among African Americans in North Carolina. J. Am. Diet. Assoc. 2005, 105, 392-402. [CrossRef] [PubMed]

48. Richardson, N. 'The “buck" stops with me'-reconciling men's lay conceptualisations of responsibility for health with men's health policy. Health Sociol. Rev. 2010, 19, 419-436. [CrossRef]

49. Beseler, C.L.; Keeney, A.J.; Garratt, R.; Wertheimer, A.; Stallones, L. Assessing Connections in an Agricultural Community Using Social Network Analysis. J. Agromed. 2021, 26, 245-255. [CrossRef]

50. Bonevski, B.; Randell, M.; Paul, C.; Chapman, K.; Twyman, L.; Bryant, J.; Brozek, I.; Hughes, C. Reaching the hard-to-reach: A systematic review of strategies for improving health and medical research with socially disadvantaged groups. BMC Med. Res. Methodol. 2014, 14, 42. [CrossRef]

51. Drahota, A.; Meza, R.D.; Brikho, B.; Naaf, M.; Estabillo, J.A.; Gomez, E.D.; Vejnoska, S.F.; Dufek, S.; Stahmer, A.C.; Aarons, G.A. Community-Academic Partnerships: A Systematic Review of the State of the Literature and Recommendations for Future Research. Milbank Q. 2016, 94, 163-214. [CrossRef]

52. van Doorn, D.; Richardson, N.; Osborne, A.; Blake, C. The impact of a workplace cardiovascular health screening programme 'Farmers Have Hearts' on health behaviour change among Irish farmers. Work 2019, 63, 113-123. [CrossRef] 